\title{
ACTUAL MENTAL STATE OF STUDENTS IN PROCESS OF PHYSICAL EDUCATION CLASSES
}

\author{
Ekaterina Kovalevskaya \\ Pskov State University, Russian Federation \\ Irina Kolbasova \\ Pskov State University, Russian Federation \\ Elena Karpenko \\ Pskov State University, Russian Federation
}

\begin{abstract}
The transformation of the education system is taking place in modern Russia. There is a transition to a flexible learning system, adapted to the educational needs of every person with any age, cultural, linguistic affiliation. Practical training disciplines are becoming increasingly important. Academic disciplines that form universal competencies are transferred to online learning. Physical Education is such disciplines. All theoretical training is translated online, and the share of classes in the gym is minimized. The purpose of this pilot study is to identify the actual mental state of students in the gym in the conditions of using game and competitive methods. In addition, an important task is to compare the well-being, activity and mood of students studying physical education in the gym and online. An adapted version of the Dembo-Rubinstein technique was used to diagnose such indicators of the current mental state as well-being, activity and mood. The dynamics of these indicators in the conditions of employment in the gym using game and competitive methods was studied using a formative experiment. It was established that real classes in the gym have a positive effect on the actual mental state of students. Most students have improved health, mood, and increased activity. At the same time, classes using the game method, in contrast to classes using the competitive method, are much more effective for activating students and improving their mood. Comparison of indicators of the actual mental state of students in real classes in the gym and online showed that classes in the gym are able to more effectively influence the mood and activity of students. Keywords: activity, classes in the gym, current mental state, interactive teaching methods, mood, online training, well-being.
\end{abstract}

\section{Introduction}

The progressive development of science and technology stimulate intensive changes in modern society, especially in the socio-economic sphere. Technological progress, greening, digitalization, expanding the network space, complicating the structure of society itself are becoming conditions for changing the world of professions and educational needs of a person. Specialized professional skills lose their relevance. Universal flexible skills (Soft Skills) 
become necessary in vocational education. Flexible skills include systemic thinking, the ability to work in a team, entrepreneurial thinking, the ability to manage projects, creativity, communication skills, knowledge of modern information technologies, ecological thinking, the ability to work effectively in conditions of uncertainty, customer focus, etc. These skills are an important condition for the effective functioning of the subject of labor in an ever-changing world. In this regard, an innovative model of education is being actively introduced in Russia. This model has the following features:

- Flexibility and variability (the need for sustainable educational programs that have been implemented for many years is decreasing, while the importance of new long-term and short-term educational programs oriented to the constantly changing labor market needs increases);

- Continuous monitoring of the situation of the labor market and the educational needs of the population;

- $\quad$ Rejection of the standard lecture and seminar form of training in favor of the project form of work; project method and practical training are methods that contribute to the more effective development of Soft Skills;

- $\quad$ The increasing role of business and work experience (business and employers are both customers of educational programs and teachers, since training in practice communities is also very effective);

- The active introduction of online learning due to the intensive development of information systems;

- Expansion of the geography of the educational space (training should leave the walls of universities and schools, move to cities, parks, libraries, shopping centers, etc.;

- Educational programs are creative;

- Educational programs have a narrow focus (programs should be aimed at the formation of certain skills and competencies. For example, universities should train not just managers in the broad sense, but managers for a specific current field of the economy, for example, managers for managing online sales).

In this regard, a significant number of academic disciplines that are focused on the development of cultural, universal competencies are transferred to online learning. Physical Education (PE) is such a discipline. All theoretical training is transferred to online courses, and classes in the gym are reduced to a minimum.

The purpose of this pilot study is to determine the actual mental state of students in the gym, since the effectiveness of the educational process largely 
depends on the activity of the students, their positive attitude and interest in the work. In addition, we formulate the following research questions:

- Are there any significant differences in the actual mental state of students in real physical education classes in the gym and online?

- Are there any significant differences in the actual mental state of students in physical education classes in the gym using various methods of interactive training?

This study examines two interactive learning methods - the game method and the competitive method.

\section{Literature review}

The problem of the influence of physical education classes on the mental and physical condition of students is relevant for modern science. It is studied by (Borkovits, 2013; Cherkashin, Platonov, \& Migalkin, 2015; Dirlewanger, Di Vetta, Giusti, Schneiter, Jéquier, \& Tappy 1999; Oleynik \& Annenko, 2018) and others. Most researchers consider the formation of certain skills, physical and physiological characteristics in physical education classes in the gym. Scientists do not study the problem of the influence of physical education on a mental state practically.

Actual mental state is an integral characteristic of mental activity for a certain period of time. It reflects the uniqueness of the functioning of mental processes depending on the reflected objects and phenomena of reality, the previous state and personality traits (Levitov, 1964).

V.F. Sopov believes that the current mental state has an effect on a person in the process of physical activity as follows (Sopov, 2005):

- $\quad$ The structure of individual consciousness is transformed;

- The subjective significance of certain events in training and competition changes;

- $\quad$ The meaning of events is being transformed.

A.A. Derkach indicates that the mental state is determined, like all mental phenomena, primarily environmental influences. Physical condition also affects him. Mental states depend on the individual characteristics of a person, as well as on his previous conditions of his functioning. Mental states are determined by internal and external factors, in this way (Derkach, 2012).

Well-being, activity and mood are the main indicators of the current mental state.

Thus, the current mental state is a characteristic of the student's mental activity in physical education classes. It reflects the features of the functioning of the individual in these specific conditions, depending on the mental representation of reality. 
Kovalevskaya et al., 2020. Actual Mental State of Students in Process of Physical Education Classes

\section{Methodology}

The formative experiment method was used in this study.

The following methodological positions were taken into account when organizing the experiment and choosing diagnostic methods:

- The need to establish the initial severity of the mental state (Levitov, 1964);

- $\quad$ It is possible to apply subjective methods of data collection in the study of mental conditions; This position is based on the idea that the subjective is a reflection in the human mind of objective manifestations (Zinchenko, 2010; Ganzen \& Yurchenko, 1981).

The experiment was conducted on the basis of Pskov State University in the framework of "Elective disciplines in physical education and sports."

58 first-year students of different educational fields took part in the experiment. The age of the group members is 17-19 years.

The experiment consisted of two stages:

The first stage is practical exercises in the gym. 8 practical exercises (16 hours) were conducted during the experiment: 4 lessons using the game method and 4 lessons using the competitive method. All tasks in the gym were based on the use of only a specific teaching method, including introductory and final exercises.

The second stage is the study of the theoretical foundations of physical education in the framework of the online distance course "Physical Education" (24 hours), developed at the Baltic State University named after I. Kant.

Diagnosis of well-being, activity and mood was carried out at the beginning and at the end of each lesson using the method of studying self-assessment T.V. Dembo - S.Ya. Rubinstein. Evaluation criteria and procedure were changed in accordance with the goals of the study. The use of this technique was due to the fact that it is possible to evaluate the necessary indicators quickly using it. The procedure for using the Dembo-Rubinstein technique to diagnose the health, activity and mood of high school students was as follows:

- Students received an answer form that presented three scales with criteria for well-being, activity and mood for self-assessment at the beginning of the lesson and the same three scales for self-assessment at the end of the lesson. Students received the task: "Here are three scales that reflect your well-being, activity and mood at the moment. The upper pole of these scales corresponds to good health, mood, high activity, the lower pole to poor. Remember the moment, the situation from your life, when you felt very good, absolutely healthy, happy, active, when you were just overwhelmed with energy, your soul was 
joyful and pleasant. This state corresponds to the upper pole of the scale. And now remember the moment when you felt very bad, you had a bad mood and you did not want anything. This state corresponds to the lower pole of the scales. Your task is to evaluate your state at the moment, compare it with these extreme options and put a point on the scale in the place that, in your opinion, corresponds to your well-being, activity and mood at the moment”. Students were given a second instruction at the end of the lesson: "Here are three scales that reflect your well-being, mood and activity. Your task is to compare how your state has changed after the lesson and the exercises that you performed. Try not to take into account other factors that could change your wellbeing, activity and mood (for example, thoughts about homework, control work, etc.), and put a point in the place on the scale where you consider it necessary".

The control of additional variables was carried out as follows:

- Comfortable physical conditions for classes were created (the same spacious room was always used - a gym with good lighting);

- The effects of the experimenter's influence were reduced (uniform appearance, rejection of value judgments and criticism, which could ruin the mood of the group members);

- $\quad$ The influence of external factors was minimized (group members left all personal items, including mobile phones, in the locker room);

- $\quad$ The effect of intra-group pressure was reduced (the introduction of rules of conduct and work in the gym).

The processing of empirical data was carried out using methods of mathematical statistics.

Thus, well-being, activity and mood, as well as their dynamics are measured indicators of the actual mental state of students in the classroom in the gym.

\section{Research results}

The first research task is to determine the actual mental state of students in physical education classes in the gym.

The dynamics of well-being, activity, and mood before and after each lesson were the focus of attention in this study. Data on the dynamics of "well-being" in the classroom using the game and competitive methods are presented in table 1. 
Kovalevskaya et al., 2020. Actual Mental State of Students in Process of Physical Education Classes

Table 1 Dynamics of well-being (in \%) at physical education classes using game and competitive methods in the gym

\begin{tabular}{|l|c|c|c|c|c|c|c|c|}
\hline Number of lesson & 1 & 2 & 3 & 4 & 5 & 6 & 7 & 8 \\
\hline Method & $\mathrm{G}$ & $\mathrm{C}$ & $\mathrm{G}$ & $\mathrm{C}$ & $\mathrm{G}$ & $\mathrm{C}$ & $\mathrm{G}$ & $\mathrm{C}$ \\
\hline $\begin{array}{l}\text { Positive dynamics } \\
\text { of well-being }\end{array}$ & 71 & 51 & 62 & 60 & 72 & 69 & 78 & 59 \\
\hline $\begin{array}{l}\text { Negative dynamics } \\
\text { of well-being }\end{array}$ & 12 & 28 & 19 & 26 & 17 & 26 & 19 & 28 \\
\hline $\begin{array}{l}\text { Well-being has not } \\
\text { changed }\end{array}$ & 17 & 21 & 19 & 14 & 12 & 5 & 3 & 13 \\
\hline $\begin{array}{l}\text { W } \\
\text { p }\end{array}$ & $\begin{array}{l}4.513 \\
0.000\end{array}$ & $\begin{array}{l}2.450 \\
0.014\end{array}$ & $\begin{array}{l}3.556 \\
0.000\end{array}$ & $\begin{array}{l}2.851 \\
0.004\end{array}$ & $\begin{array}{l}4.220 \\
0.000\end{array}$ & $\begin{array}{c}2.990 \\
0.003\end{array}$ & $\begin{array}{l}4.950 \\
0.000\end{array}$ & $\begin{array}{c}2.955 \\
0.003\end{array}$ \\
\hline
\end{tabular}

Legend: «G» is a game method; «C» is a competitive method; «W» is the value of the Wilcoxon test; «p» is the significance level.

The results show that there was a positive dynamics of well-being in all classes in general, that is, students had a subjective feeling of improvement. If we consider students who have deterioration in well-being, then the results show that the well-being worsened in a large number of students in the classroom using the competitive method.

Data on the dynamics of the "mood" of students in physical education classes using game and competitive methods are presented in table 2 .

The nature of the changes in mood shows that mood improved in the vast majority of students in all classes, regardless of the method used.

Table 2 Dynamics of mood (in \%) at physical education classes using game and competitive methods in the gym

\begin{tabular}{|l|c|c|c|c|c|c|c|c|}
\hline Number of lesson & 1 & 2 & 3 & 4 & 5 & 6 & 7 & 8 \\
\hline Method & $\mathrm{G}$ & $\mathrm{C}$ & $\mathrm{G}$ & $\mathrm{C}$ & $\mathrm{G}$ & $\mathrm{C}$ & $\mathrm{G}$ & $\mathrm{C}$ \\
\hline $\begin{array}{l}\text { Positive dynamics } \\
\text { of mood }\end{array}$ & 81 & 66 & 83 & 82 & 81 & 71 & 91 & 88 \\
\hline $\begin{array}{l}\text { Negative dynamics } \\
\text { of mood }\end{array}$ & 5 & 17 & 10 & 9 & 10 & 17 & 2 & 5 \\
\hline $\begin{array}{l}\text { Mood has not } \\
\text { changed }\end{array}$ & 14 & 17 & 7 & 9 & 9 & 12 & 7 & 7 \\
\hline $\begin{array}{l}\text { W } \\
\text { p }\end{array}$ & $\begin{array}{l}5.570 \\
0.000\end{array}$ & $\begin{array}{l}3.136 \\
0.002\end{array}$ & $\begin{array}{l}5.648 \\
0.000\end{array}$ & $\begin{array}{c}5.372 \\
0.000\end{array}$ & $\begin{array}{c}5.917 \\
0.000\end{array}$ & $\begin{array}{c}4.777 \\
0.000\end{array}$ & $\begin{array}{c}6.000 \\
0.000\end{array}$ & $\begin{array}{c}6.160 \\
0.000\end{array}$ \\
\hline
\end{tabular}

Legend: «G» is a game method; «C» is a competitive method; "W» is the value of the Wilcoxon test; «p» is the significance level.

Data on the dynamics of "activity" among students in physical education classes in the gym using game and competitive methods are presented in table 3. 
Table 3 Dynamics of activity (in \%) at physical education classes using game and competitive methods in the gym

\begin{tabular}{|l|c|c|c|c|c|c|c|c|}
\hline Number of lesson & 1 & 2 & 3 & 4 & 5 & 6 & 7 & 8 \\
\hline Method & $\mathrm{G}$ & $\mathrm{C}$ & $\mathrm{G}$ & $\mathrm{C}$ & $\mathrm{G}$ & $\mathrm{C}$ & $\mathrm{G}$ & $\mathrm{C}$ \\
\hline $\begin{array}{l}\text { Positive dynamics } \\
\text { of activity }\end{array}$ & 79 & 74 & 81 & 76 & 86 & 71 & 82 & 72 \\
\hline $\begin{array}{l}\text { Negative dynamics } \\
\text { of activity }\end{array}$ & 12 & 17 & 14 & 14 & 8 & 24 & 9 & 16 \\
\hline $\begin{array}{l}\text { Activity has not } \\
\text { changed }\end{array}$ & 9 & 9 & 5 & 10 & 6 & 5 & 9 & 12 \\
\hline $\begin{array}{l}\text { W } \\
\text { p }\end{array}$ & $\begin{array}{l}5.771 \\
0.000\end{array}$ & $\begin{array}{l}4.220 \\
0.000\end{array}$ & $\begin{array}{l}5.218 \\
0.000\end{array}$ & $\begin{array}{l}4.952 \\
0.000\end{array}$ & $\begin{array}{l}5.980 \\
0.000\end{array}$ & $\begin{array}{c}4.384 \\
0.000\end{array}$ & $\begin{array}{c}5.372 \\
0.000\end{array}$ & $\begin{array}{c}4.994 \\
0.000\end{array}$ \\
\hline
\end{tabular}

Legend: «G» is a game method; «C» is a competitive method; «W» is the value of the Wilcoxon test; «p» is the significance level.

The results show that most students had an increase in the level of activity in all classes. If we consider the data on the decrease in activity, then the results show that the percentage of students with negative dynamics of activity in the classroom using the competitive method is slightly higher.

Thus, the results of the study show that classes in the gym affect the current mental state of students favorably, namely: contribute to improving well-being, mood and increase activity.

The second goal of this study is to determine whether there are significant differences in the actual mental state of students in physical education classes using game and competitive methods.

The data analysis procedure included three stages:

1. The coefficient of the dynamics of well-being, activity and mood is calculated by subtracting from the assessment after the lesson and the assessment before the lesson (calculations were carried out relative to each lesson);

2. The arithmetic average of the coefficients of the dynamics of wellbeing, activity and mood for all classes using one and the second method was calculated;

3. The comparison of the average dynamics coefficients for classes using the game and competitive methods was carried out using the MannWhitney criterion.

Significant differences were identified by two indicators: (figure 1 ):

1. In the mood dynamics $(U=846 ; p=0.000)$.

2. In the dynamics of activity $(\mathrm{U}=1141 ; \mathrm{p}=0.003)$. 
Kovalevskaya et al., 2020. Actual Mental State of Students in Process of Physical Education Classes

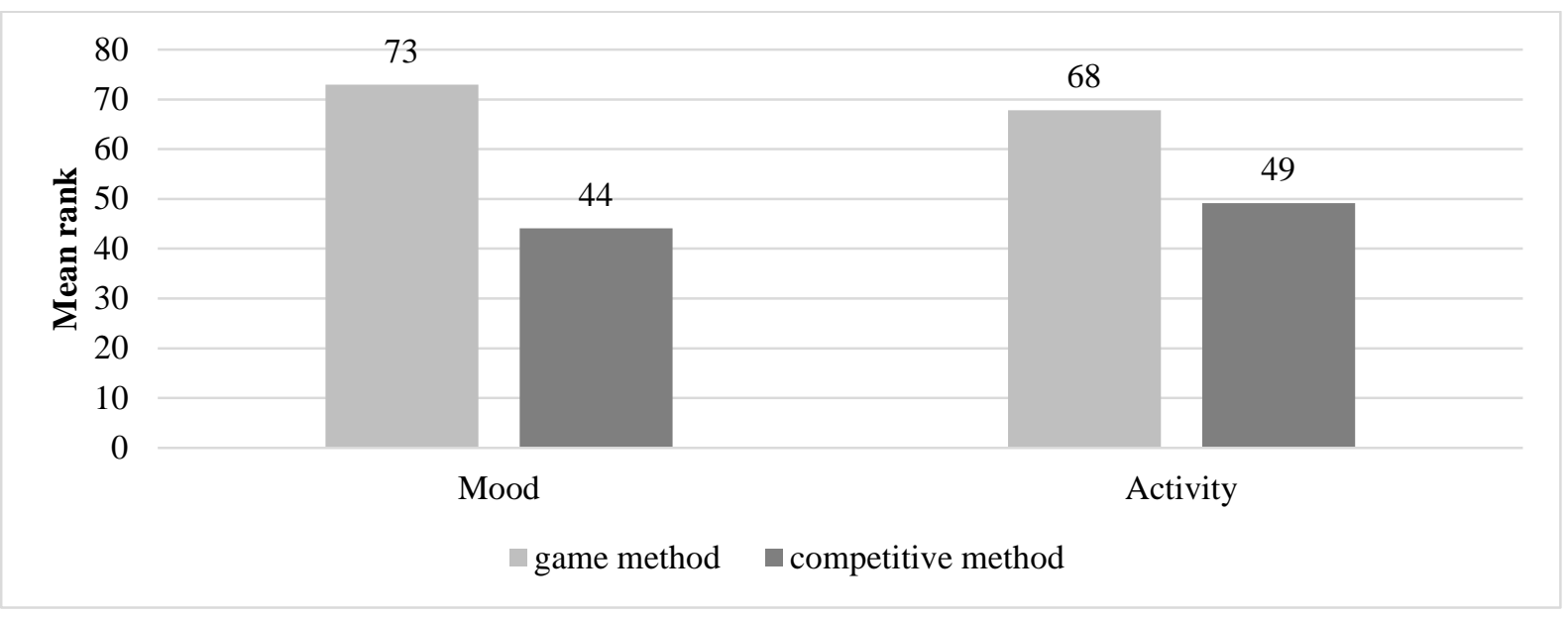

Figure 1 Significant differences in the dynamics of mood and activity of students in physical education classes in the gym using the game and competitive method

Analysis of these differences allows us to conclude that classes using the game method are more effective in terms of influencing the mood and activity of students. Perhaps this is due to the fact that this method does not limit students in their actions, and inclusion in the game is always associated with some element of emotionality and excitement. The competitive method makes more demands on the accuracy of the exercises, and also imposes greater responsibility on the participants. Such conditions create a situation of psychological tension, the actualization of internal conflicts related to competition, level of claims, group responsibility.

Thus, the use of the game method allows you to relieve the student's inner tension, improve his mood and increase his activity level.

The third objective of this study is to identify significant differences in the actual mental state of students in physical education in the gym, and to study the course on an online platform.

Students in online mode were asked to answer the questionnaire before and after studying the course to solve this research problem. The duration of the online course was two weeks. Students had to remember how they felt, mood and activity throughout all online classes, in the process of self-assessment. Significant dynamics of well-being, activity and mood were identified using the Wilcoxon test (table 4).

The results show that most students had a negative dynamics of well-being, mood and activity. This means that the well-being worsens, the mood deteriorates and the activity of students decreases when learning physical education online. Perhaps this is due to the fact that self-study online occurs most often in the evening, designed for students to relax. In addition, it reduced functional state at that time according to the daily dynamics of the individual's performance. 
Table 4 Dynamics of well-being, activity and mood (in \%) among students on the online course "Physical Education"

\begin{tabular}{|c|c|c|c|}
\hline Number of lesson & Well-being & Mood & Activity \\
\hline Positive dynamics of indicator & 25 & 24 & 25 \\
\hline Negative dynamics of indicator & 60 & 62 & 64 \\
\hline Indicator has not changed & 15 & 14 & 11 \\
\hline W & -3.289 & -3.547 & -3.037 \\
p & 0.001 & 0.000 & 0.002 \\
\hline
\end{tabular}

Thus, the results of the experiment showed that a positive dynamics of wellbeing, activity and mood is observed when learning physical education in the gym. Indicators of the current mental state decrease when studying this course online. Therefore, it is important to maintain the physical activity of students in the gym in a sufficient amount. Real classes should be regular. Online classes should only complement classes in the gym. Such training conditions are the key to maintaining satisfactory health, activity and good mood among students. The online load should be minimized, as it is implemented at a time intended for rest and relaxation. These conditions create a pronounced stress and deplete the nervous system of the individual.

\section{Conclusions and discussion}

The following conclusions were obtained as a result of the study:

1. Physical education in the gym are affected the current mental state of students favorably. They help to improve well-being, mood and increase activity.

2. The game method is more effective in class in the gym for activating students and improving their mood and emotional background compared to the competitive method.

3. Classes in the gym are more effective than classes on the online platform. Classes in the gym cause an improvement in well-being, increased activity and a mood boost. The negative dynamics of these indicators is observed when studying online.

The results obtained show the importance of physical education for maintaining the health and activity of students. Therefore, it is necessary to include physical education in the curriculum of undergraduate and specialty. Online learning can only complement the PE process.

Of course, online education has many advantages, namely: removes the spatial and temporal boundaries of training, expands the possibilities of individual choice, and offers a wide range of content. This is good when studying a significant number of academic disciplines, but not physical education. Physical 
Kovalevskaya et al., 2020. Actual Mental State of Students in Process of Physical Education Classes

education is aimed at managing the development of physical qualities, abilities and training in motor actions. All classes should be conducted with the participation of a trainer, whose task is to monitor the correct implementation of the exercises by students.

In addition, it is necessary to remember the importance of joint activity of students, which contributes not only to physical development, but also improves the condition of students, increases their mood and the level of their general activity. Students receive a boost of energy, positive emotions, which improve the mood for the whole day. At the same time, interactive teaching methods are effective in organizing physical education classes, especially game and competitive methods. Students note that performing exercises in a team contributes to a sense of self-confidence, and also unites the group, improving the psychological climate in the student team.

Thus, a pilot study established the importance of physical activity to improve the current mental state of students. The data obtained will be supplemented by subsequent studies on a larger sample. But now we can state the fact that physical education classes, conducted only under the supervision of a trainer, are an important condition for ensuring their health as a resource for achieving high working capacity and productivity.

\section{References}

Borkovits, M. (2013). Happiness in Physical Education Classes. Journal of Novel Physiotherapies, 3(3), 1-4.

Cherkashin, I.A., Platonov, D.N., \& Migalkin, A.G. (2015). Izuchenie individual'notipologicheskih svojstv vysshej nervnoj dejatel'nosti i sensomotornyh funkcij studentov, zanimajushhihsja tajskim boksom. Uspehi sovremennogo estestvoznanija, 9(3), 576-578.

Dirlewanger, M., Di Vetta, V., Giusti, V., Schneiter, P., Jéquier, E., \& Tappy, L. (1999). Effect of Moderate Physical Activity on Plasma Leptin Concentration in Humans. European Journal of Applied Physiology, 79(4). 331-335.

Derkach, A.A. (2012). Metodologicheskie sostavljajushhie sostojanija psihicheskoj gotovnosti k dejatel'nosti. Akmeologija, 3(43), 10-19.

Ganzen V.A. (1981). Sistemnyj podhod $\mathrm{k}$ analizu, opisaniju i jeksperimental'nomu issledovaniju psihicheskih sostojanij cheloveka. V V.A. Ganzen \& V.N. Jurchenko (Ed.), Jeksperimental'naja i prikladnaja psihologija (pp. 5-16). Leningrad: Izdatel'stvo Leningradskogo universiteta.

Levitov, N.D. (1964). O psihicheskih sostojanijah cheloveka. M.: Prosveshhenie.

Olejnik, E.A., \& Annenko V.V. (2018). Fizkul'turno-ozdorovitel'naja napravlennost' zanjatijami pilatesom $\mathrm{v}$ formirovanii zdorovogo obraza zhizni zhenshhiny $\mathrm{v}$ gorodskoj srede. Uchenye zapiski universiteta im. P. F. Lesgafta, 6(160), 139-143.

Sopov, V.F. (2005). Psihicheskie sostojanija $v$ naprjazhennoj professional'noj dejatel'nosti, ucheb. posobie dlja studentov vuzov fizkul'tur. profilja. Moskva: Ros. gos. un-t fiz. kul'tury, sporta i turizma.

Zinchenko, V.P. (2010). Soznanie i tvorcheskij akt. Moskva: Jazyki slavjanskih kul'tur. 